\title{
Mapping international practice patterns in EUS-guided tissue sampling: outcome of a global survey
}

Authors

Institution
Priscilla A. van Riet, Djuna L. Cahen, Jan-Werner Poley, Marco J. Bruno

Department of Gastroenterology and Hepatology, Erasmus MC University Medical Center Rotterdam, Rotterdam, The Netherlands submitted 23. October 2015 accepted after revision 5. January 2016

\section{Bibliography}

Dol http://dx.doi.org/

10.1055/s-0042-101023

Endoscopy International Open

2016; 04: E360-E370

(c) Georg Thieme Verlag KG

Stuttgart · New York

E-ISSN 2196-9736

\section{Corresponding author}

Priscilla Anita van Riet, MD

Department of

Gastroenterology and

Hepatology

Erasmus MC University Medical

Center Rotterdam

P.O Box 2040

3015 CE Rotterdam

the Netherlands

Fax: +31107032908

p.vanriet@erasmusmc.nl
Background and study aims: Although Endoscopic Ultrasound (EUS)-guided tissue sampling is widely used, the optimal sampling strategy remains subject of debate. We evaluated practice patterns within the international endosonographic community.

Patients and methods: An online questionnaire was sent to 400 endosonographers from the United States, Europe, and Asia.

Results: A total of 186 (47\%) endosonographers participated: United States 54 (29\%), Europe 85 (46\%), and Asia 47 (25\%). European (75\%) and Asian (84\%) respondents routinely check coagulation status, whereas US respondents only check on indication (64\%, $P=0.007)$. While propofol sedation is standard in the United States (83\%), conscious sedation is still widely used in Europe (52\%) and Asia $(84 \%, P<0.001)$. Overall, the $22-$ gauge needle is most commonly used (52\%). For fine-needle aspiration (FNA) of solid pancreatic

\section{Introduction}

\section{$\nabla$}

Endoscopic ultrasound (EUS)-guided tissue sampling is a safe and accurate modality for diagnosing and staging lesions in and around the gastrointestinal tract [1]. It enables clinicians to obtain a tissue diagnosis during real-time imaging, using fine-needle aspiration (FNA) or fine-needle biopsy (FNB). The diagnostic accuracy of these sampling techniques ranges from $52 \%$ to $98 \%$ and is influenced by several factors including target lesion characteristics, operator skills, needle size and type, sampling techniques, presence of an on-site pathologist, and specimen handling and processing [2-9].

To provide endosonographers with some guidance, both the American and European Society of Gastrointestinal Endoscopy (ASGE and ESGE) issued a set of guidelines [10-16]. In 2011, the ESGE published practice guidelines on EUS-guided tissue sampling, covering its indications, learn- lesions, 22-gauge (45\%) and 25-gauge (49\%) needles are used equally. For fine-needle biopsy (FNB) of solid masses, the 25-gauge device is less favored than the 22-gauge FNA device (49\% versus $21 \%$ ). The 19-gauge needle is generally used for FNB of submucosal masses (62\%). Rapid onsite pathological evaluation (ROSE) is utilized more often by US (98\%) than by European and Asian respondents $(51 \%, P<0.001)$. Cytolyt $(52 \%)$, formalin (15\%) and alcohol (15\%) are used for FNA specimen preservation in the United States and Europe, while saline (27\%) and alcohol (38\%) are widely used in Asia $(P<0.001)$.

Conclusions: EUS-guided tissue sampling practices vary substantially within the international endosonographic community and differ considerably from recommendations expressed in guidelines. Because the clinical relevance of these variations is largely unknown, the outcome of this survey suggests a need for further studies.

ing phase, techniques, complications, and results $[11,12]$. They were updated in 2013 , adding two new techniques; elastography and contrast enhanced ultrasound [16]. The ASGE has issued practice guidelines concerning sedation, antibiotic prophylaxis, and prevention of adverse events. In addition, the Papanicolaou Society of Cytopathology (PSC), one of the leading societies in cancer cytopathology, published guidelines addressing EUS cytology techniques, terminology, ancillary studies, and post-procedure management $[17,18]$. $\odot$ Table 1 compares their most important recommendations. Unfortunately, due to the limited number of well-conducted studies in this field, many of these recommendations lack firm scientific evidence. As a result, today's practice mainly relies on local hospital protocols, expert opinions, and personal preferences.

Although EUS-guided tissue sampling is globally established, little is known about intercontinental variations in clinical practice. It is also unknown 
Table 1 Recommendations for EUS-guided tissue sampling from the ASGE, ESGE, and Papanicolaou Society of Cytopathology.

\begin{tabular}{|c|c|c|c|}
\hline & ASGE & ESGE & Papanicolaou Society of Cytopathology \\
\hline \multirow[t]{2}{*}{ Anticoagulant use } & & $\begin{array}{l}\text { - Check coagulation status in patients } \\
\text { with personal or family history sug- } \\
\text { gesting bleeding disorder or with a } \\
\text { clear clinical indication. }\end{array}$ & \\
\hline & $\begin{array}{l}\text { - EUS-FNA of solid lesions can be per- } \\
\text { formed in patients on aspirin or } \\
\text { NSAIDS, but not in patients on thie- } \\
\text { nopyridines. }\end{array}$ & $\begin{array}{l}\text { - EUS-FNA of solid lesions can be per- } \\
\text { formed in patients on aspirin or } \\
\text { NSAIDS, but not in patients on thie- } \\
\text { nopyridines. }\end{array}$ & \\
\hline $\begin{array}{l}\text { Antibiotic } \\
\text { prophylaxis }\end{array}$ & $\begin{array}{l}\text { - Recommended before sampling of } \\
\text { cystic lesions. }\end{array}$ & $\begin{array}{l}\text { - Recommended before sampling of } \\
\text { cystic lesions. }\end{array}$ & \\
\hline \multirow[t]{2}{*}{ Sedation } & $\begin{array}{l}\text { - Propofol provides more rapid onset } \\
\text { of action and shorter recovery time. } \\
\text { No proof of higher patient satisfac- } \\
\text { tion or better safety. Cost-effective- } \\
\text { ness for average-risk patients is not } \\
\text { proven. }\end{array}$ & $\begin{array}{l}\text { - Propofol provides higher post-proce- } \\
\text { dural patient satisfaction, decreases } \\
\text { time to sedation and recovery. } \\
\text { No proof of cost-effectiveness. }\end{array}$ & \\
\hline & $\begin{array}{l}\text { - On-site anesthesiologist suggested } \\
\text { in presence of patient-related risk } \\
\text { factors. }\end{array}$ & $\begin{array}{l}\text { - On-site anesthesiologist suggested } \\
\text { in presence of patient-related risk } \\
\text { factors. }\end{array}$ & \\
\hline Needle size & & $\begin{array}{l}\text { - 19-gauge, } 22 \text {-gauge and } 25 \text {-gauge } \\
\text { needles have similar diagnostic yields } \\
\text { and safety profiles. } \\
\text { 19G should not be used for } \\
\text { transduodenal puncturing. }\end{array}$ & $\begin{array}{l}\text { - Generally: } 22 \text {-gauge or } 25 \text {-gauge } \\
\text { - Vascular mass: } 25 \text {-gauge } \\
\text { - Lymph nodes: } 25 \text {-gauge } \\
\text { - Mucinous cyst: } 22 \text {-gauge } \\
\text { - Fibrotic stromal rich mass: } 19 \text {-gauge }\end{array}$ \\
\hline Number of passes & & $\begin{array}{l}\text { - Cysts: } 1 \\
\text { - Solid pancreatic: } \geq 5 \\
\text { - Lymph nodes: } 3\end{array}$ & $\begin{array}{l}\text { - Cysts: } 1 \\
\text { - Solid pancreatic: } 5-7 \\
\text { - Lymph nodes: }<5 \\
\text { - Stromal cell tumor: } 3-5\end{array}$ \\
\hline Suction & & $\begin{array}{l}\text { - Applying continuous suction with a } \\
\text { syringe is recommended in solid } \\
\text { masses but not in lymph nodes. }\end{array}$ & \\
\hline
\end{tabular}

how available practice guidelines are implemented in current local sampling routines. The purpose of this study, therefore, was to: 1) map the practice patterns in EUS-guided tissue sampling in today's endosonographic community; 2) identify differences and concordances between endosonographers from the United States, Europe and Asia; and 3) compare the current practice patterns to the guidelines of the ASGE and ESGE.

\section{Patients and methods \\ $\nabla$}

\section{Selection of study subjects}

An online questionnaire was sent out per e-mail to endosonographers from the United States, Europe, and Asia. Registered endosonographers were selected by 1) using the personal network of the research team, which consists of national and international experts in the field, and 2) performing a PubMed literature search to identify authors who have published on the topic of EUS-guided tissue sampling in the last 10 years. Not only first authors but all listed authors were approached. Consent to participate in the study was inferred from voluntary completion of the survey.

\section{Questionnaire}

The survey consisted of a maximum of 65 multiple-choice questions and was designed to take less than 10 minutes to complete (Appendix 1) and was divided into four sections. The first part focused on demographics including gender, age, country of residence, type and size of current practice, years of experience, training and familiarity with EUS and EUS-guided tissue sam- pling. The second part included questions regarding peri-procedural use of anticoagulants, antibiotics, and sedation. The third part contained questions on preferred equipment and sampling techniques and whether these preferences depend upon target lesion type (pancreatic solid or cystic mass, lymph node or submucosal mass). The final part of the survey examined practice patterns regarding tissue processing and analysis.

\section{Questionnaire administration}

All endosonographers were approached by e-mail with a study invitation and were provided with a personal, direct link to the survey. This link was inactivated once the survey was completed. A reminder was sent by e-mail, after 2, 4, and 6 weeks. Subjects who did not respond within 4 weeks thereafter were considered to be non-respondents.

\section{Statistical analysis}

Only completed surveys were used for data analysis. For comparison between continents, the Chi-squared or Kruskal Wallis test was applied. All reported $P$ values are two-sided and a value $<0.05$ was considered to be significant. Data were analysed with SPSS 22, Statistical Package for the Social Sciences, SPSS Inc., Chicago, Illinois. 
Table 2 Demographics and practice details of survey respondents per continent.

\begin{tabular}{|c|c|c|c|c|}
\hline Variables & $\begin{array}{l}\text { All } \\
n=186(100 \%)\end{array}$ & $\begin{array}{l}\text { US } \\
n=54(29 \%)\end{array}$ & $\begin{array}{l}\text { Europe } \\
n=85(46 \%)\end{array}$ & $\begin{array}{l}\text { Asia } \\
n=47(25 \%)\end{array}$ \\
\hline Age, years [Median IQR] & $46(41-52)$ & $44,5(41-54)$ & $47(41-52)$ & $43(40-49)$ \\
\hline Male gender [Median IQR] & $168(90)$ & $48(89)$ & $77(91)$ & $43(92)$ \\
\hline \multicolumn{5}{|l|}{ Specialty } \\
\hline Gastroenterology & $178(96)$ & $54(100)$ & $78(91)$ & $46(98)$ \\
\hline Other & $8(4)$ & & $7(9)$ & $1(2)$ \\
\hline \multicolumn{5}{|l|}{ Type of hospital } \\
\hline Academi & $146(78)$ & $48(89)$ & $64(76)$ & $34(72)$ \\
\hline Community & $24(13)$ & $2(4)$ & $17(20)$ & $5(11)$ \\
\hline Other & $16(9)$ & $4(8)$ & $4(4)$ & $8(17)$ \\
\hline Years of experience [Median IQR] & $13(8-20)$ & $13(5-22.25)$ & $14(9-20)$ & $12(8-18)$ \\
\hline \multicolumn{5}{|l|}{ EUS procedures/yr. } \\
\hline$<100$ & $7(4)$ & $0(0)$ & $5(6)$ & $2(4)$ \\
\hline $100-200$ & $33(18)$ & $7(13)$ & $11(13)$ & $15(32)$ \\
\hline $200-300$ & $37(20)$ & $15(28)$ & $15(18)$ & $7(15)$ \\
\hline$>300$ & $109(58)$ & $32(59)$ & $54(63)$ & $23(49)$ \\
\hline \multicolumn{5}{|l|}{ EUS-FNA/yr. } \\
\hline$<50$ & $16(9)$ & $2(4)$ & $6(7)$ & $8(17)$ \\
\hline $50-100$ & $44(24)$ & $11(20)$ & $20(24)$ & $13(28)$ \\
\hline $100-200$ & $53(28)$ & $17(32)$ & $20(24)$ & $16(34)$ \\
\hline$>200$ & $73(39)$ & $24(44)$ & $39(45)$ & $10(21)$ \\
\hline Formal EUS-training & $114(61)$ & $37(69)$ & $48(57)$ & $29(62)$ \\
\hline
\end{tabular}

Abbrieviation: EUS, endoscopic ultrasound; FNA, fine-needle aspiration; IQR, interquartile range; US, United States

Table 3 Anticoagulation and antiplatelet management for EUS-guided tissue sampling per continent.

\begin{tabular}{|c|c|c|c|c|c|}
\hline Variables & $\begin{array}{l}\text { All } \\
n=99(\%)\end{array}$ & $\begin{array}{l}\text { US } \\
n=11(\%)\end{array}$ & $\begin{array}{l}\text { Europe } \\
n=56 \text { (\%) }\end{array}$ & $\begin{array}{l}\text { Asia } \\
n=32(\%)\end{array}$ & $P$ value $^{1}$ \\
\hline \multicolumn{6}{|c|}{ Routine coagulation check } \\
\hline Always & $73(74)$ & $4(36)$ & $42(75)$ & $27(84)$ & 0.007 \\
\hline On indication & $26(26)$ & $7(64)$ & $14(25)$ & $5(16)$ & \\
\hline \multicolumn{6}{|c|}{ Anticoagulant stopped } \\
\hline Acetylsalicylic acid & $23(23)$ & $0(0)$ & $7(13)$ & $16(50)$ & $<0.001$ \\
\hline Thienopyridines & $80(81)$ & $8(73)$ & $47(84)$ & $25(78)$ & 0.618 \\
\hline Heparin & $83(84)$ & $11(100)$ & $42(75)$ & $30(94)$ & 0.022 \\
\hline Coumarins & $72(73)$ & $5(46)$ & $48(86)$ & $19(59)$ & 0.003 \\
\hline NOACs & $80(81)$ & $10(91)$ & $49(88)$ & $21(66)$ & 0.029 \\
\hline
\end{tabular}

Abbreviations: US, United States; NOACs, new oral anticoagulants.

${ }^{1} \mathrm{~A}$ chi square test was used to compare the three continents.

\section{Results}

\section{$\nabla$}

\section{Demographics}

A total of 400 endosonographers were approached, of whom 197 responded (49\%). Eleven responses were discarded because they were incomplete, which resulted in 186 participants (47\%): 54 from the United States (29\%), 85 from Europe (46\%), and 47 from Asia (25\%, $\bigcirc$ Table 2, Appendix 2). The majority of the respondents were male (90\%) gastroenterologists (96\%), working in an academic setting (79\%), and performing $>300$ EUS (58\%) and $>100$ EUS-FNA procedures per year (68\%).

\section{Preprocedural practice patterns}

\section{Coagulation status}

In preparation for the procedure, most European (75\%) and Asian (84\%) respondents report that they "always check" coagulation status, while their US colleagues generally do so on indication ( Table 3, $P=0.007$ ). Acetylsalicylic acid is generally continued (77\%), but that differed between continents. US respondents always continue acetylsalicylic acid, as compared to $87 \%$ of Euro- pean and $50 \%$ of Asian respondents ( Table $3, P<0.001$ ). Regarding the use of heparin, coumarin, and new oral anticoagulants (NOACs), there is little consensus. While heparin is discontinued by all US and most Asian respondents (94\%), it is stopped by $75 \%$ of the Europeans $(P=0.022)$. The opposite is true for coumarin, which is stopped more often in Europe (86\%) than in the United States (46\%) and Asia (59\%, $P=0.003)$. In analogy, European respondents less often perform tissue sampling in patients with an international normalized ratio (INR) $>1.5$ (11\%), as compared to non-European respondents (33\%, $P=0.008$ ). Lastly, NOACs are discontinued by virtually all US (91\%) and European (88\%) endosonographers, as compared to $66 \%$ of Asian respondents $(P=0.029)$.

Antibiotic prophylaxis

In all continents, the majority of respondents use antibiotic prophylaxis for EUS-guided tissue sampling (77\%); mostly depending on the indication (92\%), but some use antibiotics routinely (8\%). Of those endosonographers who report prescribing antibiotics on indication, virtually all use it when sampling a cystic 
Table 4 Antibiotic prophylaxis for EUS-guided tissue sampling; the United State as compared to Europe and Asia.

\begin{tabular}{|c|c|c|c|c|}
\hline & $\begin{array}{l}\text { All } \\
n=132(\%)\end{array}$ & $\begin{array}{l}\text { US } \\
n=38(\%)\end{array}$ & $\begin{array}{l}\text { Europe + Asia } \\
n=94(\%)\end{array}$ & $P$ value $^{1}$ \\
\hline \multicolumn{5}{|l|}{ Antibiotic prophylasis } \\
\hline Prosthetic valve & $41(31)$ & $6(16)$ & $35(37)$ & 0.012 \\
\hline Vascular graft & $17(13)$ & $1(3)$ & $16(17)$ & 0.018 \\
\hline History of IE & $52(39)$ & $5(13)$ & $47(50)$ & $<0.001$ \\
\hline History of CHD & $19(14)$ & $2(5)$ & $17(18)$ & 0.045 \\
\hline Lesion lower gastrointestinal tract & $44(33)$ & $13(34)$ & $31(33)$ & 0.523 \\
\hline
\end{tabular}

Abbreviations: US, United States; IE, infectious endocarditis; CHD, congenital heart disease

${ }^{1}$ A chi square test was used to compare Europe and Asia with the US.

\begin{tabular}{|c|c|c|c|}
\hline FNA & All $n=88(\%)$ & FNB & All $n=72$ (\%) \\
\hline Overall & & Overall & \\
\hline 25-gauge & $86(24)$ & 25-gauge & $34(12)$ \\
\hline 22-gauge & $192(55)$ & 22-gauge & $150(52)$ \\
\hline 19-gauge & $74(21)$ & 19-gauge & $104(36)$ \\
\hline Pancreatic cystic lesion & & Pancreatic cy & \\
\hline 25-gauge & $4(5)$ & 25-gauge & $4(6)$ \\
\hline 22-gauge & $61(69)$ & 22-gauge & $49(68)$ \\
\hline 19-gauge & $33(26)$ & 19-gauge & $19(26)$ \\
\hline Pancreatic solid lesion & & Pancreatic sc & \\
\hline 25-gauge & $43(49)$ & 25 -gauge & $15(21)$ \\
\hline 22-gauge & $40(46)$ & 22-gauge & $35(49)$ \\
\hline 19-gauge & $5(5)$ & 19-gauge & $22(31)$ \\
\hline Lymph node & & Lymph node & \\
\hline 25 -gauge & $33(38)$ & 25 -gauge & $13(18)$ \\
\hline 22-gauge & $48(54)$ & 22-gauge & $41(57)$ \\
\hline 19-gauge & $7(8)$ & 19-gauge & $18(25)$ \\
\hline Submucosal mass & & Submucosal & \\
\hline 25-gauge & $6(7)$ & 25 -gauge & $2(2)$ \\
\hline 22-gauge & $43(49)$ & 22-gauge & $25(35)$ \\
\hline 19-gauge & $39(44)$ & 19-gauge & $45(63)$ \\
\hline
\end{tabular}

Abbreviations; FNA, fine-needle aspiration; FNB, fine-needle biopsy

lesion (95\%) [12]. A minority prescribes antibiotics for other indications, such as a prosthetic cardiac valve, vascular graft, previous infective endocarditis, or congenital heart disease $(<39 \%, \bullet$ Table 4). US physicians reported the lowest use of antibiotic prophylaxis.

\section{Sedation and anesthesia}

Almost all endosonographers sedate their patients during EUSguided tissue sampling (98\%). Propofol is generally used in the United States ( $83 \%)$, whereas conscious sedation is still used by $52 \%$ of European and $84 \%$ of Asian respondents $(P<0.001)$. All US respondents who use propofol have anesthesia personnel in the endoscopy room (100\%), compared to only $66 \%$ in Europe and $50 \%$ in Asia $(P<0.001)$.

\section{Sampling techniques and equipment}

Target lesion size While half of the respondents perform EUSFNA, regardless of the lesion diameter, the other half has a preferred minimum size of $0.5 \mathrm{~cm}(32 \%), 1 \mathrm{~cm}(17 \%)$, or $2 \mathrm{~cm}(1 \%)$. For EUS-FNB, most respondents confine to a minimum size of $1 \mathrm{~cm}$ (59\%). European respondents perform EUS-FNB of lesions $<1 \mathrm{~cm}$ more often $(51 \%)$ than non-European respondents $(34 \%, P=$ 0.014).

Needle size The gross of respondents prefers a specific needle size for FNA (84\%) and FNB (75\%), depending on the position of the scope or the location of the target lesion (66\%). Overall, the 22-gauge needle is most popular ( $\bullet$ Table 5 ). However, for FNA of solid pancreatic lesions, 22 -gauge ( $45 \%$ ) and 25 -gauge (49\%) needles are used equally, and for FNA of submucosal lesions, besides the 22 -gauge ( $44 \%$ ), the 19 -gauge needle ( $49 \%$ ) is frequently used. For FNB of submucosal masses, most respondents use the 19 -gauge needle (62\%). Responses did not differ between continents.

Number of passes Generally, respondents perform two to three needle passes for FNA (49\%) and FNB (57\%). Most respondents adjust the number of passes according to the target lesion. In pancreatic cysts, a single pass is performed for FNA (81\%) and FNB (76\%). For FNA of solid pancreatic masses, two to three (46 $\%$ ) or more than three needle passes are performed (50\%). For FNB of solid pancreatic masses, most respondents report carrying out only two to three passes (70\%). A minority report doing more than three passes (26\%). Asian respondents vary their number of needle passes less often (47\%) than European $(69 \%)$ and US respondents ( $63 \%, P=0.037$ ).

Sampling technique Fanning is the preferred needle motion technique for FNA (64\%). For FNB, fanning (44\%) and only moving "to and fro" (46\%) are favored equally. To increase the yield of EUSFNA, most endosonographers apply suction with a syringe (47\%) or use the slow-pull technique (42\%). Most respondents use dry instead of wet suction (93\%). Also for FNB, most endosonogra- 
phers use an additional technique to increase the yield (70\%): slow pull (53\%), suction (44\%), or a combination (3\%). Some respondents adjust the sampling technique according to the target lesion (38\%). While the slow-pull technique is mostly used for solid pancreatic masses (58\%) and lymph nodes (62\%), suction is generally applied for pancreatic cysts (82\%) and submucosal lesions (48\%).

\section{Tissue processing and analysis}

Preservation and optimization After FNA, a majority of the endosonographers prepare glass slides (65\%), which they fixate in alcohol (45\%) or leave to air dry (43\%). As for liquid-based cytology, Cytolyt is generally used to preserve FNA specimens in the United States (50\%) and Europe (53\%), while in Asia, both saline (28\%) and alcohol $(38 \%)$ are used $(P<0.001)$. Formalin is mostly used to preserve FNB or histologic tissue specimens (62\%). In order to increase the yield of sampling, most respondents also prepare and analyze tissue cores after FNA (73\%) or cytological material after FNB (73\%). Asian respondents more often look for tissue cores after FNA (96\%) than European (68\%) and US respondents $(61 \%, P<0.001)$.

ROSE Rapid on-site pathological evaluation (ROSE) is available to $65 \%$ of endosonographers. Virtually all US respondents use ROSE (98\%), compared to only half of respondents from Europe (48\%) and Asia (55\%, $P<0.001)$. Reasons for omitting ROSE included "limited pathology staffing" (74\%), "disbelieve in its additive value" (32\%), "high costs" (24\%), and "additional procedure time" (24\%).

Ancillary techniques The majority of respondents apply the cellblock technique (85\%). In the United States, almost all endosonographers use cellblock (96\%), while it is used to a lesser extent in Europe (85\%) and Asia (70\%, P=0.002). Immunohistochemical analysis is also available for most respondents (96\%), and generally used for diagnosing and staging submucosal masses (91\%), solid pancreatic lesions (75\%) and lymph nodes (70\%).

\section{Discussion \\ $\nabla$}

To the best of our knowledge, no study has investigated practice trends in EUS-FNA guided tissue sampling with respect to the current ASGE and ESGE guidelines. This survey identified substantial intercontinental differences in EUS-guided tissue sampling. Interestingly, some routines vary considerably from the recommendations expressed in existing guidelines.

We found that sedation with propofol is custom in the United States, but not in Asia and Europe. In the past, conscious sedation was standard of care, but procedures have become lengthier and more complex, requiring higher doses of sedatives. Propofol is appreciated as an alternative, because it provides a deep level of sedation with a short recovery time. However, costs may be higher, due to the need of aneasthesiological assistance in most countries $[13,19,20]$. Because cost-effectiveness of sedation with propofol has not been established, the American and European Society of Gastroenterology do not take a stand on this subject $[11,13]$. Although we did not ask participants for the reasons behind their choice, previous studies have suggested that the increased use of propofol in the United States is caused by: 1) the believe that it improves the diagnostic accuracy of EUS-guided tissue sampling; 2) efforts to offset falling procedure reimbursements; and 3) marketing strategies of anesthesiologists $[13,21$, 22].
The second interesting finding involves differences in anticoagulation and antiplatelet management. While respondents from the United States generally check coagulation status on indication only, European and Asian respondents do this more routinely. Interestingly, the practice of the US respondents, rather than that of the Europeans, seems to follow the ESGE guidelines, which recommend checking coagulation status only in selected patients, that is, those using anticoagulant or antiplatelet therapy or who have a (family) history of a bleeding disorder. Both the ASGE and ESGE recommend not discontinuing acetylsalicylic acid, while all other anticoagulation and antiplatelet therapy should be stopped $[12,23]$. In contrast to US respondents, not all European and Asian respondents adhere to this recommendation. One explanation might be that US physicians adhere to guidelines more promptly, possibly as a consequence of an increased chance for malpractice claims in the United States $[24,25]$. The relatively high number of Asian respondents who discontinue acetylsalicylic acid may be a reflection of the fact that bleeding risks are weighted more heavily in Asia. It has been suggested that Asians are more susceptible to bleeding complications, while whites are more at risk for thromboembolic events [26]. However, the Japan Gastroenterological Endoscopy Society has recently revised their guidelines, emphasizing the thromboembolism risks of discontinuation of antithrombotic agents [27]. Therefore, a shift toward continuance of acetylsalicylic acid is to be expected.

Another interesting finding of this survey is that for solid pancreatic masses, endosonographers report performing fewer needle passes with FNB than with FNA. This finding is line with recently published data about using FNB to establish a diagnosis in solid pancreatic masses [28-31]. The ESGE recommends performing at least five passes for FNA of solid pancreatic masses, in the absence of ROSE. Neither the ASGE not the ESGE recommend a minimum number of passes for FNB.

Also noteworthy is that, overall, most respondents reported using the 22-gauge needle more often than the 25-gauge needle. This finding is especially interesting, since two recent meta-analyses found no differences between the two needles, with regard to diagnostic accuracy, the number of needle passes, or complications $[8,32]$. In fact, a trend towards better performance of the 25-gauge needle for FNA of solid pancreatic masses was observed in these studies. The ESGE guideline states that, although there is no difference in diagnostic yield and safety profiles, the 25-gauge needle performs somewhat better with regard to number of required needle passes, presumably due to its higher flexibility [12]. The Papanicolaou Society of Cytopathology (PSC), recommends adapting the needle size to the target lesion. For highly vascular lesions and lymph nodes they recommend a 25-gauge needle, for mucinous cysts a 22-gauge needle, and for fibrotic or stromal-rich lesions, a 19-gauge needle [17].

Another important outcome of this survey is the intercontinental variation in use of rapid on-site pathological evaluation. Whereas virtually all US respondents use ROSE, only half of the European and Asian respondents do. Respondents who refrain from using ROSE state that they consider it too time consuming and that reimbursement for pathology services is too low. However, more than two-thirds of our respondents also mention that they have doubts with regard to the added benefit of ROSE, which might be influenced by ESGE recommendations of the ESGE stating that ROSE should only be implemented at sites where specimen adequacy rates are below $90 \%$ or during the learning curve of EUSFNA $[12,33]$. In contrast, the PSC recommends the use of ROSE whenever possible [17]. 
The last, but certainly not least remarkable finding concerns the preservation of the tissue samples. After procurement, EUS-FNA specimens are susceptible to damage by colonizing bacteria and to autolysis by enzyme activity. To halt these processes, it must be placed in a fixative (e.g., formalin, CytoRich Red, Cytolyt) or physiologic solution (e.g., saline, Hanks' salt solution). Although most of the respondents use formalin to preserve histologic samples, there is no consensus regarding preservation of cytological samples. While a majority of the Asian respondents store cytology in alcohol or saline, their European and US colleagues store it in Cytolyt. Although there are currently no guidelines on this topic, we did not expect to find such striking differences among the three continents. It would be interesting to investigate the influence of preservation methods on the specimen's quality and diagnostic accuracy, as this aspect is under-investigated so far. Our survey has some potential limitations. First, it seems conceivable that our results have been subject to a response bias, given our response rate of $47 \%$. Although our response rate still falls at the high end of the spectrum of responses for online surveys amongst physicians (1-10), it might have caused a selection towards the more active, academic endosonographers. Although most respondents indeed reported to work in high-volume academic centers, only $61 \%$ had participated in a formal EUS training program. This could have accounted for the low adherence to the practice guidelines. Currently, the ESGE and ASGE advise that a dedicated fellowship should last 6 to 24 months [12,34]. However, they also acknowledge that there is a lack of sufficient EUStraining and training capacity in Europe and the United States $[35,36]$. Because most respondents in the current study are EUS experts, the number of formally trained endosonographers and the adherence to the guidelines is likely to be even lower in nonacademic, low-volume centers. Last, a reporting or goodwill bias is likely to exist, since that is inevitable for retrospective surveys that are based on self-reporting. If respondents indeed gave an expected answer rather than a true answer, that would only strengthen our main conclusion that practice patterns for EUSguided tissue sampling differ and are not congruent with the guidelines. In conclusion, this survey shows that there is considerable intercontinental variation in the practice of EUS-guided tissue sampling. Despite of the growing number of studies in the field of EUS-guided tissue sampling, the optimal sampling strategy remains subject to debate. Moreover, some routines vary considerably from recommendations stated in existing guidelines. Further studies are required to determine the relevance and impact of various practices on outcome and safety. Pending these outcomes, cost-effectiveness studies may be required to support the implementation of a certain sampling strategies.

\section{Appendix 1 International EUS Survey \\ $\nabla$}

Background Information

1. What is your gender?

$\square$ Female

$\square \quad$ Male

\section{What is your age?}

Please write your answer here:

3.What is your specialty?

$\square$ Gastroenterologist

$\square$ Surgeon

$\square \quad$ Other

4. In which year did you finish your training?

Please write your answer here:

\section{In what country are you currently working?}

Please write your answer here:

\section{In what kind of hospital are you currently working?}

(More than one option possible)

Please choose all that apply:

$\square$ Community hospital

$\square$ Academic/University hospital

$\square \quad$ Private hospital or independent endoscopy unit

$\square \quad$ Other, please specify:

\section{How many EUS procedures do you perform each year?}

Please choose only one of the following:
$\square \quad<100$
$100-200$
200-300
$\square \quad>300$ perform each year?
Please choose only one of the following:
$\square<50$
$\square \quad 50-100$
$\square \quad 100-200$
$\square>200$

8. How many EUS-guided tissue-sampling procedures do you

9. Did you have formal training in performing EUS guided tissue sampling? (Formal training is defined as a fellowship in a dedicated EUS training center for at least 3 months)

Please choose only one of the following:

$\square$ Yes

$\square \quad$ No

\section{Preparation for EUS guided tissue sampling}

\author{
10. Do you use any type of sedation when performing EUS-guided \\ tissue sampling? \\ Please choose only one of the following: \\ $\square \quad$ Yes, conscious sedation, continue to 12 \\ $\square$ Yes, propofol \\ $\square \quad$ No, not as standard practice, continue to 12
}


11. Is anesthesia personnel routinely present during the procedure?

Please choose only one of the following:

$\square$ Yes

$\square \quad$ No

12. Do you use antibiotic prophylaxis when performing EUS-guided tissue sampling?

Please choose only one of the following:

$\square \quad$ Yes, always, continue to 14

$\square$ Yes, depending on the indication

$\square \quad$ No, continue to 14

13. Please specify for which indication you use $A B$ prophylaxis? (More than 1 answer possible)

Please choose all that apply:

$\square \quad$ Cystic lesions

$\square \quad$ Prosthetic cardiac valve

$\square$ Vascular graft

$\square \quad$ History of previous infective endocarditis

$\square$ Congenital heart disease

$\square$ Solid lesions of lower gastrointestinal tract

$\square$ Other, please specify:

14. Do you routinely check the coagulation parameters before EUS-guided tissue sampling?

Please choose only one of the following:

$\square \quad$ Yes

$\square \quad$ No, continue to 18

15. Please specify when you check coagulation status?

(More than one answer possible)

Please choose only one of the following:

$\square$ Always

$\square \quad$ In patients on anticoagulants

$\square \quad$ In patients with a (family) history of bleeding disorder

$\square$ In both, patients on anticoagulants and patients with a (family) history of bleeding disorder

16. Which of the following anticoagulants do you generally discontinue, prior to a puncture procedure? (More than one answers possible)

Please choose all that apply:

$\square \quad$ Acetylsalicylic acid (Aspirin, Carbasalate calcium [Ascal], Dipyridamole [Persantin])

$\square \quad$ Thienopyridines (Clopidogrel [Plavix, Grepid, Iscover, Vatoud], Prasugrel [Effient])

$\square$ Coumarin derivatives (Acenocoumarol [Sintrom], Phenprocoumon [Marcoumar, Marcumar, Falithrom])

$\square$ Heparin or derivatives (Warfarin [Coumadin], Dalteparin [Fragmin], Nadroparin [Fraxiparin], Tinzaparin [Innohep])

$\square \quad$ New Oral Anticoagulant drugs (NOAC) (Rivaroxaban [Xarelto], Apixaban [Eliquis], Dabigatran [Pradax])

$\square$ Other, please specify:
17. Up to which INR value would you consider it safe to perform EUS-guided tissue sampling?

Please choose only one of the following:

口 INR 1.0

$\square \quad$ INR $1.1-1.5$

$\square \quad$ INR $1.6-2.0$

$\square \quad$ INR $>2.0$

This section contains questions about Fine Needle Aspiration

18. What is the minimum lesion diameter for you to consider FNA?

Please choose only one of the following:

$\square \quad$ No minimum

$\square \quad 0.5 \mathrm{~cm}$

$\square \quad 1 \mathrm{~cm}$

$\square \quad 2 \mathrm{~cm}$

19. Do you have a preferred needle size for FNA?

Please choose only one of the following:

$\square$ Yes

$\square \quad$ No, continue to 21

20. Does your preferred needle size depend on scope position and/or location of target lesion?

Please choose only one of the following:

$\square \quad$ Yes, continue to 22

$\square \quad$ No

21. Which needle size do you generally prefer?

Please choose only one of the following

19G

22G

25G

22. Specify if your preferred needle size depends on: (More than one answer possible)

Please choose all that apply:

$\square \quad$ Location of target lesion,

$\square \quad$ Scope position, continue to 24

23. Please specify your preferred needle size for the following indications:

Please choose the appropriate response for each item:

$\begin{array}{llll} & 19 G & 22 G & 25 G \\ \text { Pancreatic solid mass } & \square & \square & \square \\ \text { Pancreatic cystic mass } & \square & \square & \square \\ \text { Lymph node } & \square & \square & \square \\ \text { Submucosal mass } & \square & \square & \square\end{array}$

24. Please specify your preferred needle size for the following scope positions:

Please choose the appropriate response for each item:

$\begin{array}{llll} & 19 \mathrm{G} & 22 \mathrm{G} & 25 \mathrm{C} \\ \text { Transgastric } & \square & \square & \square\end{array}$

Transduodenal D1 (Superior

part/Duodenal bulb)

Transduodenal D2

(Descending part)

Transduodenal D3

(Horizontal part) 
25. Does your number of needle passes depend on the indication for FNA?

Please choose only one of the following:

$\square$ Yes

$\square \quad$ No, continue to 27

26. Please specify the number of needle passes per indication. Please choose the appropriate response for each item:

$\begin{array}{llll} & 1 & 2-3 & >3 \\ \text { Pancreatic solid mass } & \square & \square & \square \\ \text { Pancreatic cystic mass } & \square & \square & \square \\ \text { Lymph node } & \square & \square & \square \\ \text { Submucosal mass } & \square & \square & \square\end{array}$

27. Please specify the number of needle passes you generally perform.

Please choose only one of the following:
$\square \quad 1$
$\square \quad 2-3$
ㅁ $>3$

28. What is your preferred needle movement technique during FNA?

Please choose only one of the following:
$\square \quad$ To \& Fro
$\square \quad$ Fanning
$\square \quad$ No preferred technique

29. Which additional techniques do you employ to increase the yield of tissue sampling during FNA?

Please choose only one of the following:
$\square \quad$ Slow pull
$\square$ Syringe
$\square \quad$ Wet suction
$\square$ Capillary technique
$\square \quad$ None
$\square \quad$ Other, please specify

30. How do you expel sampling material from the FNA needle? (More than one answer possible)

Please choose all that apply:

$\square \quad$ Flushing with air

$\square \quad$ Flushing with saline

$\square \quad$ With stylet

31. Do you use on-site pathological evaluation of the specimen? Please choose only one of the following:
$\square$ Yes, always
$\square \quad$ Yes, sometimes
$\square \quad$ No, continue to 33

32. Please specify who performs on-site pathological evaluation. Please choose only one of the following:
$\square$ Pathologist
Cytotechnician
$\square \quad$ Myself

33. Why are you not using on-site pathological evaluation? (More than one answer possible)

Please choose all that apply:

$\square \quad$ No added benefit with regard to yield

$\square$ Costs

$\square \quad$ Time

$\square \quad$ Expertise

$\square \quad$ No pathological personnel available

$\square \quad$ Other, please specify

34. Do you prepare glass slides after you performed FNA? Please choose only one of the following:

$\square$ Yes

$\square \quad$ No, continue to 37

35. How do you fixate these smears?

Please choose only one of the following:

$\square \quad$ Air dry

$\square \quad$ Direct fixation with alcohol

$\square \quad$ Other, please specify

36. Which preservation medium do you use to collect cytology, obtained with FNA?

Please choose only one of the following:

$\square$ Saline

$\square$ Cytolyt

$\square \quad$ A fixative (formalin)

$\square$ Hanks

$\square$ Alcohol

$\square \quad$ Other, please specify

37. Is the cell block technique applied in your center? Please choose only one of the following:

$\square$ Yes

$\square \quad$ No

38. Do you or your pathologist routinely look for tissue cores after FNA?

Please choose only one of the following:

$\square$ Yes, always, continue to 40

$\square$ Yes, depending on the target lesion

No, continue to 44

39. Please specify for which indication(s) you look for tissue cores after FNA? (More than one answer possible)

Please choose all that apply:

$\square$ Cystic pancreatic lesions (from solid components or cyst wall)

$\square$ Solid pancreatic lesions

․ Lymph nodes

$\square \quad$ Submucosal lesion

40. Are these tissue cores processed differently compared to the cytological tissue sample?

Please choose only one of the following:

$\square \quad$ Yes

$\square \quad$ No, continue to 44 


\section{They are collected in a separate vial?}

Please choose only one of the following:

Yes

$\square$ No

42. They are collected in a different medium?

lease choose only one of the following:

$\square$ Yes

$\square \quad$ No

43. In what medium?

Please choose only one of the following:

$\square$ Saline

$\square$ Cytolyt

$\square \quad$ A fixative (formalin)

$\square$ Hanks

$\square$ Alcohol

This section contains questions about Fine Needle Biopsy

44. What is the minimum lesion diameter for you to consider FNB?

Please choose only one of the following:

$\square \quad$ No minimum

$\square \quad 0.5 \mathrm{~cm}$

ㅁ $1 \mathrm{~cm}$

口 $2 \mathrm{~cm}$

45. Do you have a preferred needle size for FNB?

Please choose only one of the following:

$\square \quad$ Yes, continue to 47

$\square \quad$ No

46. Which needle size do you generally prefer?

Please choose only one of the following:
19G
22G
25G

47. Does your preferred needle size depend on scope position and/or location of target lesion?

Please choose only one of the following:

$\square \quad$ Yes, continue to 49

$\square \quad$ No

48. Which needle size do you generally prefer?

Please choose only one of the following

19G

22G

$\square \quad 25 \mathrm{G}$

49. Specify if your preferred needle size depends on:

(More than one answer possible)

Please choose all that apply:

$\square \quad$ Location of target lesion

$\square \quad$ Scope position, continue to 51
50. Please specify your preferred needle size for the following indications:

Please choose the appropriate response for each item:

$\begin{array}{llll} & 19 \mathrm{G} & 22 \mathrm{G} & 25 \mathrm{G} \\ \text { Pancreatic solid mass } & \square & \square & \square \\ \text { Pancreatic cystic mass } & \square & \square & \square \\ \text { Lymph node } & \square & \square & \square \\ \text { Submucosal mass } & \square & \square & \square\end{array}$

51. Please specify your preferred needle size for the following scope positions:

Please choose the appropriate response for each item:

$\begin{array}{llll} & 19 G & 22 G & 25 G \\ \text { Transgastric } & \square & \square & \square \\ \text { Transduodenal D1 (Superior } & & & \\ \text { part/Duodenal bulb) } & \square & \square & \square \\ \begin{array}{l}\text { Transduodenal D2 } \\ \text { (Descending part) }\end{array} & \square & \square & \square \\ \begin{array}{l}\text { Transduodenal D3 } \\ \text { (Horizontal part) }\end{array} & \square & \square & \square\end{array}$

52. Does your number of needle passes depend on the indication for FNB?

Please choose only one of the following:

$\square$ Yes

No, continue to 54

53. Please specify the number of needle passes per indication. Please choose the appropriate response for each item:

$\begin{array}{llll} & 1 & 2-3 & >3 \\ \text { Pancreatic solid mass } & \square & \square & \square \\ \text { Pancreatic cystic mass } & \square & \square & \square \\ \text { Lymph node } & \square & \square & \square \\ \text { Submucosal mass } & \square & \square & \square\end{array}$

54. Please specify the number of needle passes you generally perform.

Please choose only one of the following:
ㅁ 1
ㄴ $2-3$
$\square>3$

55. What is your preferred needle movement technique during FNB?

Please choose only one of the following:

$\square \quad$ To \& Fro

$\square \quad$ Fanning

$\square \quad$ No preferred technique

56. Do you use a special technique (slow pull or syringe) to acquire tissue with the FNB needle?

Please choose only one of the following:

$\square \quad$ Yes, this depends on the indication

$\square$ Yes, independent of the indication, continue to 58

No, continue to 59 


\section{Please specify per indication}

Please choose the appropriate response for each item:

$$
\begin{aligned}
& \begin{array}{l}
\text { Slow Syringe Wet Capillary Other } \\
\text { pull }
\end{array} \\
& \text { suction technique }
\end{aligned}
$$

Pancreatic solid mass

Pancreatic cystic mass

Lymph node

Submucosal mass

$\begin{array}{llll}\square & \square & \square & \square \\ \square & \square & \square & \square \\ \square & \square & \square & \square \\ \square & \square & \square & \square\end{array}$

\section{Please specify}

Please choose only one of the following:
$\square$ Slow pul
$\square$ Syringe
$\square \quad$ Wet suction
$\square \quad$ Capillary technique
$\square \quad$ Other, please specify

\section{How do you expel sampling material from the FNB needle?}

(More than one answer possible)

Please choose all that apply:

$\square \quad$ Flushing with air

$\square$ Flushing with saline

$\square \quad$ With stylet

\section{Which preservation medium do you use to collect the FNB}

\section{specimen?}

Please choose only one of the following:

$\square$ Saline

$\square$ Cytolyt

$\square \quad$ A fixative (formalin)

$\square$ Hanks

$\square \quad$ Alcohol

$\square \quad$ Other, please specify

61. Is immunohistochemical analysis performed in your center? (when sufficient sampling material is available)

Please choose only one of the following:

$\square \quad$ Yes, depending on the indication

$\square$ Yes, independent of the indication, continue to 63

$\square \quad$ No, continue to 63

\section{Please specify (More than one answer possible)}

Please choose all that apply:

$\square$ Solid pancreatic mass

$\square \quad$ Lymph node

$\square$ Submucosal mass

63. Is a cytological sample also prepared and evaluated (i. e. glass slide, cyto spin), in addition to the histological tissue core specimen?

Please choose only one of the following:

$\square$ Yes

$\square \quad$ No, end of survey

64. Does this depend on the needle size?

Please choose only one of the following:

$\square$ Yes

$\square \quad$ No, end of survey

65. Please specify for which needle size you look for additional cytological sample?

Please choose all that apply:

$\begin{array}{cc}\square & 19 G \\ \square \quad 22 G \\ \square \quad 25 G\end{array}$

\begin{tabular}{|c|c|c|}
\hline Countries & Number of respondents & Percentage of total (\%) \\
\hline \multicolumn{3}{|l|}{ Europe } \\
\hline Finland & 1 & 0.5 \\
\hline Israel & 1 & 0.5 \\
\hline Latvia & 1 & 0.5 \\
\hline Scotland & 1 & 0.5 \\
\hline Belgium & 2 & 1.1 \\
\hline Ireland & 2 & 1.1 \\
\hline Norway & 2 & 1.1 \\
\hline Switzerland & 2 & 1.1 \\
\hline Sweden & 3 & 1.6 \\
\hline Germany & 7 & 3.8 \\
\hline Spain & 9 & 4.8 \\
\hline France & 10 & 5.4 \\
\hline England & 13 & 7.0 \\
\hline Netherlands & 13 & 7.0 \\
\hline Italy & 18 & 9.7 \\
\hline \multicolumn{3}{|l|}{ Asia } \\
\hline Korea & 1 & 1.6 \\
\hline India & 5 & 2.7 \\
\hline Malaysia & 5 & 2.7 \\
\hline China & 7 & 3.8 \\
\hline Singapore & 8 & 4.3 \\
\hline Japan & 19 & 10.2 \\
\hline \multicolumn{3}{|l|}{ North America } \\
\hline United States & 54 & 29 \\
\hline TOTAL & 186 & 100 \\
\hline
\end{tabular}

\section{Appendix 2 List of countries of respondents}

Competing interests: None

References

1 Huang JY, Chang KJ. Improvements and innovations in endoscopic ultrasound guided fine needle aspiration. J Hepatobiliary Pancreat Sci 2015: (DOI 10.1002/jhbp.232)

2 Iglesias-Garcia J, Dominguez-Munoz JE, Abdulkader I et al. Influence of on-site cytopathology evaluation on the diagnostic accuracy of endoscopic ultrasound-guided fine needle aspiration (EUS-FNA) of solid pancreatic masses. Am J Gastroenterol 2011; 106: 1705-1710 (DOI ajg2011119 [pii] 10.1038/ajg.2011.119)

3 Pellise Urquiza M, Fernandez-Esparrach G, Sole M et al. Endoscopic ultrasound-guided fine needle aspiration: predictive factors of accurate diagnosis and cost-minimization analysis of on-site pathologist. Gastroenterol Hepatol 2007; 30: 319-324 (DOI 13107565 [pii])

4 Erickson RA, Sayage-Rabie L, Beissner RS. Factors predicting the number of EUS-guided fine-needle passes for diagnosis of pancreatic 
malignancies. Gastrointest Endosc 2000; 51: 184-190 (DOI S0016510700797264 [pii])

5 Iwashita T, Nakai Y, Samarasena JB et al. High single-pass diagnostic yield of a new 25-gauge core biopsy needle for EUS-guided FNA biopsy in solid pancreatic lesions. Gastrointest Endosc 2013; 77: 909-915 (DOI S0016-5107(13)00002-3 [pii] 10.1016/j.gie.2013.01.001)

6 Larghi A, Iglesias-Garcia J, Poley JW et al. Feasibility and yield of a novel 22-gauge histology EUS needle in patients with pancreatic masses: a multicenter prospective cohort study. Surg Endosc 2013; 27: 3733 3738 (DOI 10.1007/s00464-013-2957-9)

7 Bang JY, Hebert-Magee S, Trevino J et al. Randomized trial comparing the 22-gauge aspiration and 22-gauge biopsy needles for EUS-guided sampling of solid pancreatic mass lesions. Gastrointest Endosc 2012; 76: 321 - 327 (DOI S0016-5107(12)01679-3 [pii] 10.1016/j.gie.2012. 03.1392)

8 Madhoun MF, Wani SB, Rastogi A et al. The diagnostic accuracy of 22gauge and 25-gauge needles in endoscopic ultrasound-guided fine needle aspiration of solid pancreatic lesions: a meta-analysis. Endoscopy 2013; 45: 86 - 92 (DOI 10.1055/s-0032-1325992)

9 Eckardt AJ, Adler A, Gomes EM et al. Endosonographic large-bore biopsy of gastric subepithelial tumors: a prospective multicenter study. Eur J Gastroenterol Hepatol 2012; 24: 1135-1144 (DOI 10.1097/MEG.0b013e328356eae2)

10 Early DS, Acosta RD. Committee ASoP. et al. Adverse events associated with EUS and EUS with FNA. Gastrointest Endosc 2013; 77: 839-843 (DOI S0016-5107(13)00176-4 [pii] 10.1016/j.gie.2013.02.018)

11 Dumonceau JM, Polkowski M, Larghi A et al. Indications, results, and clinical impact of endoscopic ultrasound (EUS)-guided sampling in gastroenterology: European Society of Gastrointestinal Endoscopy (ESGE) Clinical Guideline. Endoscopy 2011; 43: 897-912 (DOI 10.1055/s-0030-1256754)

12 Polkowski M, Larghi A, Weynand B et al. Learning, techniques, and complications of endoscopic ultrasound (EUS)-guided sampling in gastroenterology: European Society of Gastrointestinal Endoscopy (ESGE) Technical Guideline. Endoscopy 2012; 44: 190-206 (DOI 10.1055/s0031-1291543)

13 Lichtenstein DR, Jagannath S. Standards of Practice Committee of the American Society for Gastrointestinal E. et al. Sedation and anesthesia in GI endoscopy. Gastrointest Endosc 2008; 68: 815-826 (DOI S00165107(08)02617-5 [pii] 10.1016/j.gie.2008.09.029)

14 Jue TL, Sharaf RN. Committee ASoP. et al. Role of EUS for the evaluation of mediastinal adenopathy. Gastrointest Endosc 2011; 74: 239-245 (DOI S0016-5107(11)01532-X [pii] 10.1016/j.gie.2011.03.1255)

15 Khashab MA, Chithadi KV. Committee ASoP. et al. Antibiotic prophylaxis for GI endoscopy. Gastrointest Endosc 2015; 81: 81 -89 (DOI S0016-5107(14)02077-X [pii] 10.1016/j.gie.2014.08.008)

16 Dietrich CF, Jenssen C. Endoscopic ultrasound-guided sampling in gastroenterology: European society of gastrointestinal endoscopy technical guidelines. Endosc Ultrasound 2013; 2: 117-122 (DOI 10.7178/ eus.06.001 EUS-2-117 [pii])

17 Pitman MB, Layfield LJ. Guidelines for pancreaticobiliary cytology from the Papanicolaou Society of Cytopathology: A review. Cancer Cytopathol 2014; 122: 399-411 (DOI 10.1002/cncy.21427)

18 Brugge W, Dewitt J, Klapman JB et al. Techniques for cytologic sampling of pancreatic and bile duct lesions. Diagn Cytopathol 2014; 42: 333 337 (DOI 10.1002/dc.23096)

19 McQuaid KR, Laine L. A systematic review and meta-analysis of randomized, controlled trials of moderate sedation for routine endoscopic procedures. Gastrointest Endosc 2008; 67: 910 - 923 (DOI S0016-5107 (07)03354-8 [pii] 10.1016/j.gie.2007.12.046)

20 Dewitt J, McGreevy K, Sherman S et al. Nurse-administered propofol sedation compared with midazolam and meperidine for EUS: a prospective, randomized trial. Gastrointest Endosc 2008; 68: 499-509 (DOI S0016-5107(08)00372-6 [pii] 10.1016/j.gie.2008.02.092)
21 Ootaki C, Stevens T, Vargo J et al. Does general anesthesia increase the diagnostic yield of endoscopic ultrasound-guided fine needle aspiration of pancreatic masses? Anesthesiology 2012; 117: 1044-1050 (DOI 10.1097/ALN.0b013e31826e0590)

22 Aisenberg J, Brill JV, Ladabaum $U$ et al. Sedation for gastrointestinal endoscopy: new practices, new economics. Am J Gastroenterol 2005; 100: 996-1000 (DOI AJG50034 [pii] 10.1111/j.1572-0241.2005. 50034.x)

23 Anderson MA, Ben-Menachem T. Committee ASoP. et al. Management of antithrombotic agents for endoscopic procedures. Gastrointest Endosc 2009; 70: 1060-1070 (DOI S0016-5107(09)02549-8 [pii] 10.1016/j.gie.2009.09.040)

24 Hernandez LV, Klyve D, Regenbogen SE. Malpractice claims for endoscopy. World journal of gastrointestinal endoscopy 2013; 5: 169-173 (DOI 10.4253/wjge.v5.i4.169)

25 Conklin LS, Bernstein C, Bartholomew L et al. Medical malpractice in gastroenterology. Clinical gastroenterology and hepatology : the official clinical practice journal of the American Gastroenterological Association 2008; 6: 677-681 (DOI 10.1016/j.cgh.2008.02.047)

26 Lee SY, Tang SJ, Rockey DC et al. Managing anticoagulation and antiplatelet medications in GI endoscopy: a survey comparing the East and the West. Gastrointest Endosc 2008; 67: 1076-1081 (DOI S00165107(07)03115-X [pii] 10.1016/j.gie.2007.11.037)

27 Fujimoto K, Fujishiro M, Kato M et al. Guidelines for gastroenterological endoscopy in patients undergoing antithrombotic treatment. Dig Endosc 2014; 26: 1 - 14 (DOI 10.1111/den.12183)

28 Lee YN, Moon JH, Kim HK et al. Core biopsy needle versus standard aspiration needle for endoscopic ultrasound-guided sampling of solid pancreatic masses: a randomized parallel-group study. Endoscopy 2014; 46: 1056-1062 (DOI 10.1055/s-0034-1377558)

$29 \mathrm{Hucl}$ T, Wee E, Anuradha S et al. Feasibility and efficiency of a new 22G core needle: a prospective comparison study. Endoscopy 2013; 45: 792 - 798 (DOI 10.1055/s-0033-1344217)

30 Vanbiervliet G, Napoleon B, Saint Paul MC et al. Core needle versus standard needle for endoscopic ultrasound-guided biopsy of solid pancreatic masses: a randomized crossover study. Endoscopy 2014; 46: 1063 - 1070 (DOI 10.1055/s-0034-1377559)

31 Alatawi A, Beuvon F, Grabar $S$ et al. Comparison of $22 \mathrm{G}$ reverse-beveled versus standard needle for endoscopic ultrasound-guided sampling of solid pancreatic lesions. United European Gastroenterol J 2015; 3: 343-352 (DOI 10.1177/2050640615577533 10.1177_205064061 5577533 [pii])

32 Affolter KE, Schmidt RL, Matynia AP et al. Needle size has only a limited effect on outcomes in EUS-guided fine needle aspiration: a systematic review and meta-analysis. Dig Dis Sci 2013; 58: 1026-1034 (DOI 10.1007/s10620-012-2439-2)

33 Iglesias-Garcia J, Larino-Noia J, Abdulkader I et al. Rapid on-site evaluation of endoscopic-ultrasound-guided fine-needle aspiration diagnosis of pancreatic masses. World J Gastroenterol 2014; 20: 9451-9457 (DOI 10.3748/wjg.v20.i28.9451)

34 Faigel DO, Baron TH, Adler DG et al. ASGE guideline: guidelines for credentialing and granting privileges for capsule endoscopy. Gastrointest Endosc 2005; 61: 503 -505 (DOI S0016510704027816 [pii])

35 Azad JS, Verma D, Kapadia AS et al. Can U.S. GI fellowship programs meet American Society for Gastrointestinal Endoscopy recommendations for training in EUS? A survey of U.S. GI fellowship program directors Gastrointest Endosc 2006; 64: 235-241 (DOI S0016-5107(06) 01911-0 [pii] 10.1016/j.gie.2006.04.041)

36 Wasan SM, Kapadia AS, Adler DG. EUS training and practice patterns among gastroenterologists completing training since 1993. Gastrointest Endosc 2005; 62: 914-920 (DOI S0016-5107(05)02754-9 [pii] 10.1016/j.gie.2005.08.045) 